\title{
Inquiry Learning Model to Develop Students' Skill in Conducting Experiments on Temperature, Heat, and Heat Transfer
}

\author{
Hikmawati Hikmawati* \\ Physics Education Study Program \\ Universitas Mataram \\ NTB Indonesia \\ hikmawati@unram.ac.id
}

\author{
Kusmiyati Kusmiyati \\ Biology Education Study Program \\ Universitas Mataram \\ NTB Indonesia
}

\author{
Sutrio Sutrio \\ Physics Education Study Program \\ Universitas Mataram \\ NTB Indonesia
}

\begin{abstract}
This study aimed at examining the effectiveness of the inquiry learning model (ILM) to develop students' skills in carrying out experiments on the material of temperature, heat, and heat transfer. This study involved 21 students of class XI IPA-1 at SMAN 1 Kediri in the 2017/2018 Academic Year. The skills of students trained in carrying out experiments were the ability to assemble tools, the ability to read measuring instruments, the ability to record observational data, and the ability to present experimental results. The students' skills in carrying out experiments were assessed through observing physics learning activities with the material of Temperature, Heat, and Heat Transfer within 4 meetings. The findings show that the average score of the students' ability to assemble tools is 12 (very good category), the ability to read measuring instruments is 12 (very good category), the ability to record observation data is 13 (very good category), and the ability to present experimental results is 8 (good category). Further, the average score of students' skills in carrying out experiments on the temperature, heat, and heat transfer is 11 (good category). Thus, ILM can be an alternative to physics teachers in training the skills of high school students in conducting experiments in Classes and/or in the Laboratory.
\end{abstract}

Keywords - inquiry learning, skill, trial

\section{INTRODUCTION}

Natural science, including physics, is the driving force for the development of information and communication technology that has fundamentally changed human life. In the era of globalization, the lives of many people are influenced by the development of science and technology. In order to solve problems that arise in everyday life, scientific information is required. Therefore, scientific literacy is a necessity for every individual to have a greater opportunity to adjust to the dynamics of life. As time passes, information and technology continue to develop very rapidly. Everyone must be able to understand the environmental, health, economic and other problems faced by modern society [1].

According to [2], one of the government policies in improving the quality of human resources in Indonesia is to develop an Indonesian education curriculum. In 2013, the 2013 curriculum began with the characteristics which do not only prioritizing knowledge, but also attitudes and skills which in practice use a scientific approach. The scientific approach which is used in the 2013 curriculum emphasizes the dimensions of modern pedagogic learning. The 2013 curriculum orientation is an improvement and balance between attitude competencies, skills, and knowledge. There are five stages in implementing a scientific approach to classroom learning: observing, asking, collecting data, reasoning, and communicating. Learning activities with a scientific approach is very supportive to improve students' science process skills. Following the steps of established learning activities, the students' science process skills are expected to be trained as the students gain direct experience in learning and gathering information.

Sandoval \& Reiser [3] argue that in order to build an inquiry-based classroom environment the teacher must build a community of practice like the work of scientists. In authentic inquiry-based activities, students take action as scientists do, experiencing the process of knowing and justifying knowledge. Dostál [4] revealed that the Inquiry Learning Model (ILM) is an inquiry-based learning model in education that can develop students' creative thinking to solve problems. ILM can support students in finding concepts through inquiry activities and this model can be applied at all levels of education [5]. ILM can also be applied in physics learning activities because ILM can instill creative thinking and critical analysis in students so that students have the skills to solve problems in the classroom, laboratory, practical problems related to industry, and everyday life [6].

Obomanu [7] suggested the use of ILM in learning science, including physics, because the application of ILM provides meaningful learning for students. Although based on the scientific method, inquiry-based learning is a learning model that must be considered to be used in other disciplines because it supports the development of students who are responsible for their learning [8].

The basic characteristic of ILM is that context-based learning uses 'real-life' situations which focuses on thinking skills, requires interdisciplinary knowledge integration, self-directed, develops lifelong learning skills and can be applied in small groups. Students are driven by real-life problems which can make them interested in the solutions. To solve problems, they must learn how to: actively integrate knowledge; accumulate and connect skills; and work together. The role of the teacher in ILM is 
as a facilitator, so it is clear that learning activities in ILM are student-centered [9].

Inquiry-based learning is one of the models that challenge the traditional learning concept [10]. In traditional learning, students do not have the opportunity to take an active part in the learning process unless their teacher asks them to complete assignments or throw questions. Knowledge presented by teachers usually cannot be argued, and students must accept it.

In implementing ILM, teachers are expected to have certain attitudes and competencies in encouraging students so that they succeed in inquiry-based classes. In addition, the teacher must realize that ILM has several levels and each level chosen must be in accordance with the level of competence and experience of students. The reason is that one of the keys to success in ILM is understanding that the skills and responsibilities associated with the new level can only be introduced to learners gradually over time. By knowing the level of competence of students, teachers will find it easy to design the accurate learning sequences that allow students to develop skills and expertise in science learning so that the process of inquiry learning can run well [11].

ILM is a student-centered learning model that makes students active in the learning environment. ILM can facilitate activities that encourage students to take part in the process of inquiry, problem-solving, and decision making [12]. ILM is one of the learning models that play an important role in constructing constructivist learning paradigms that emphasize student learning activeness [13]. ILM provides more opportunities for students to get the opportunity to learn how to find facts, concepts, and principles through their own direct experience. ILM also gives students the opportunity to practice developing process skill, thinking skill, and being scientific attitude [13]. In other words, the application of ILM can facilitate students to improve learning outcomes in the cognitive, affective, and psychomotor domains.

The psychomotor domain deals with learning outcomes expressed in the form of skills in completing manual tasks and physical movements or the ability to act. Learning outcomes in this domain also include social aspects such as communication skills and the ability to operate certain tools [13]. Thus, ILM can be an alternative for teachers to train students' skills in carrying out experiments. Students' skills in conducting experiments can be in the form of the ability to assemble tools, the ability to read measuring devices, the ability to record observational data, and the ability to present the results of an experiment. The purpose of this study is to describe the results of the application of the Inquiry Learning Model (ILM) in training the skills of high school students in carrying out experiments for temperature, heat and heat transfer subject materials. The choice of temperature, heat, and heat transfer material is based on the situation in which high school students still have low level mastery for the subject materials, 59.74 at the West Lombok Regency level, and 53.65 at the NTB Province level [14].

\section{METHOD}

This study is a trial of the application of inquiry learning models to train students' skills in conducting experiments on temperature, heat, and heat transfer material. The study was conducted at SMAN 1 Kediri Academic Year 2017/2018. The research subjects were 21 natural science students of class XI IPA-1. Assessment of student skills in carrying out experiments was obtained through observation in physics learning activities with ILM within 4 meetings. Students' skills in carrying out experiments that were trained through the application of ILM in this study consisted of 4 components, namely the ability to assemble tools, the ability to read measuring instruments, the ability to record observational data, and the ability to present the results of experiments. Students' skills in conducting experiments are student competencies that can be assessed in the form of students' real performance in completing the assignments during the experiments. Performance tests do not use scoring criteria that contain concepts or keywords of correct answers, but they use criteria to assess the quality of work [15]. Criteria for assessing students' skills in carrying out experiments modified by researchers based on [15], [16] can be seen in Table 1 .

TABLE I. CRITERIA FOR ASSESSING STUdENTS’ SKILL

\begin{tabular}{|l|l|l|l|}
\hline Scale & Score & Indicator & Criteria \\
\hline 4 & $12-16$ & If it's done properly and appropriate & Very Good \\
\hline 3 & $8-11$ & If it's done properly but inappropriate & Good \\
\hline 2 & $4-7$ & If it's done improperly but appropriate & Average \\
\hline 1 & Less than 4 & If it's done improperly and inappropriate & Poor \\
\hline
\end{tabular}

\section{RESULTS AND DISCUSSION}

Assessment on students' skills in conducting experiments was obtained through observations in physics learning activities for the subject material of Temperature, Heat, and Heat Transfer within 4 meetings, with a total of 6 experimental activities. The experimental activities are affixing Test Signs on Thermometers, Substance Expansion, Changes in Objects, Black Principle, Heat Transfer, and Heat Equation. Tools and materials for the experiment Test Marks on Thermometers were mercury or alcohol thermometers that have not been given a temperature scale, beaker A contains melted ice, beaker B is filled with boiling water, methanol incinerator, and colored markers. Tools and materials for the experiment The expansion of the Substance was a Musschenbroek device, a methanol incinerator, three different types of metal rods, paper, lighters. Tools and materials for the Experiment on the Transformation of Things are glass beakers, lamps, thermometers, statives, stopwatches, blocks of ice, plastic, tape, paraffin/wax. Tools and materials for the Black Principle experiment were calorimeters, beakers, thermometers, water, cube-shaped metals, methanol incinerator. Tools and materials for the 
Heat Transfer experiment are zinc, iron, glass, and copper rods with variations in length, triple feet, matches, candles or plasticine, methanol incinerator. Tools and materials for the Heat Equation experiment are beaker, thermometer, incinerator, stative, water.

Assessment on student skills in carrying out experiments on the subject material of temperature, heat, and heat transfer was in good level with an average value of 11 . The ability to record observational data obtained the highest score of 13 (very good criteria), while the ability to present the results of the experiment obtained the lowest score that is equal to 8 (good criteria). The activity of recording observational data is the easiest skill for students to do, while the activity of presenting the results of experiments is the most difficult skill for students to do. In the skills to record data, students only need to write what was observed while carrying out the experiment, while in presenting the results of the experiment students need good communication skills and analytical skills. Students must be able to provide data explanations in the form of statements, drawings, tables, and graphs to other students when students present the results of the experiment.

Observational data written by students are mostly in the form of tables. In the Substance Expansion experiment students noted observational tables in the form of metal rod types and the scale of their expansion. In the Object Changes experiment students noted changes in the appearance of material (paraffin/wax and blocks of ice) during and after the heating process. In the Black principle experiment students recorded data on metal type, water mass, calorimeter mass, mass of the stirring metal, and the scale of the temperature. In the Heat Equation experiment students record the mass of water, temperature rise, and heating time. Data in the form of graphs obtained by students when carrying out the Heat Equation experiment are graphs of temperature changes $(\Delta \mathrm{T})$ to the mass of water $(\mathrm{m})$ and $\Delta \mathrm{T}$ to $1 / \mathrm{m}$, and graphs $\Delta \mathrm{T}$ to the heating interval $(\mathrm{t})$. The assessment criteria for each component on observing students' skills in conducting experiments can be seen in Table 2.

TABLE II. CRITERIA FOR ASSESSING STUdENTS' SKILL

\begin{tabular}{|l|l|l|l|}
\hline No & Student's Skill & Mean & Criteria \\
\hline 1 & The ability to assemble tools & 12 & Very Good \\
\hline 2 & The ability to read measuring instruments & 12 & Very Good \\
\hline 3 & The ability to record observational data & 13 & Very Good \\
\hline 4 & The ability to present experimental results & 8 & Good \\
\hline
\end{tabular}

Students' skills in conducting experiments can be trained through the application of ILM. The ILM syntax used in this study refers to Jufri (2010) with 6 stages: first, identification and formulation of the problem; second, the formulation of hypotheses; third, data collection; fourth, data interpretation; fifth, developing conclusions; and sixth, repetition.

The application of ILM does not only trains students' skills in conducting experiments, but also improves students' learning outcomes in aspects of knowledge. Research conducted by Hayati [17] shows that there is an effect of ILM on the physics learning outcomes from students of class $X$. The average value of the physics learning outcomes of the experimental class using ILM is higher than the control class which uses conventional learning models. The same thing was expressed in [18] which is the effect of ILM on the physics learning outcomes from students of class XI. The average value of the physics learning achievement test of the experimental class using ILM is higher than the control class using the conventional learning model. The highest $\mathrm{N}$-gain value is in the sub-material elasticity properties and the lowest is in the sub-material of spring arrangements. This happened in the experimental class and the control class. Nevertheless, the increase is still higher in the experimental class using ILM. Another research [19] also indicated that students instructed through ILM received higher scores than those instructed through conventional models.

\section{CONCLUSION}

ILM can be used by physics teachers to train the skills of high school students in carrying out experiments in the
Classroom or in the Laboratory. Students' skills in conducting experiments that can be trained through the application of ILM are the ability to assemble tools, the ability to read measuring instruments, the ability to record observational data, and the ability to present the results of an experiment. The students' skills in carrying out experiments on the subject material for temperature, heat, and heat transfer can be categorized into good level with an average value of 11 .

\section{REFERENCES}

[1] M. I. S. Putra, W. Widodo, and B. Jatmiko, "The development of guided inquiry science learning materials to improve science literacy skill of prospective mi teachers," J. Pendidik. IPA Indones., vol. 5, no. 1, pp. 83-93, 2016.

[2] R. Hutahaean, M. B. Harahap, and D. Derlina, "The Effect of Scientific Inquiry Learning Model Using Macromedia Flash on Student's Concept Understanding and Science Process Skills in Senior High School," IOSR J. Res. Method Educ., vol. 7, no. 04, pp. 29-37, 2017.

[3] W. A. Sandoval and B. J. Reiser, "Explanation-driven inquiry: Integrating conceptual and epistemic scaffolds for scientific inquiry," Sci. Educ., vol. 88, no. 3, pp. 345-372, 2004

[4] J. Dostál, "The Definition of the Term" Inquiry-Based Instruction".," Int. J. Instr., vol. 8, no. 2, pp. 69-82, 2015.

[5] M. Windschitl, J. Thompson, and M. Braaten, "Beyond the scientific method: Model-based inquiry as a new paradigm of preference for school science investigations," Sci. Educ., vol. 92, no. 5, pp. 941-967, 2008

[6] A. Hussain, M. Azeem, and A. Shakoor, "Physics teaching methods: scientific inquiry vs traditional lecture," Int. J. Humanit. Soc. Sci., vol. 1, no. 19, pp. 269-276, 2011.

[7] B. J. Obomanu, A. U. Nwanekezi, and D. R. Ekineh, "Relative Effects of Two forms of Pedagogy on Secondary School Students 'Performance in Ecology Concepts," Int. J. Educ. Res. 2 (10), 237, vol. 250,2014 
[8] M. Smallhorn, J. Young, N. Hunter, and K. B. da Silva, "Inquirybased learning to improve student engagement in a large first year topic," Student Success, vol. 6, no. 2, pp. 65-72, 2015.

[9] C. Guohui, "Reforming organic chemistry teaching using studentcentred methods," China Pap., vol. 12, pp. 10-13, 2004.

[10] B. K. Khalaf, "Traditional and Inquiry-Based Learning Pedagogy: A Systematic Critical Review.," Int. J. Instr., vol. 11, no. 4, pp. 545-564, 2018.

[11] T. Hardianti and H. Kuswanto, "Difference among Levels of Inquiry: Process Skills Improvement at Senior High School in Indonesia.," Int. J. Instr., vol. 10, no. 2, pp. 119-130, 2017.

[12] M. Duran and İ. Dökme, "The effect of the inquiry-based learning approach on student's critical-thinking skills," Eurasia J. Math. Sci. Technol. Educ., vol. 12, no. 12, pp. 2887-2908, 2016.

[13] A. W. Jufri, Belajar dan Pembelajaran Sains. Lombok Barat: Arga Puji Press, 2010.

[14] Puspendik, "Laporan Hasil Ujian Nasional," 2015. [Online]. Available: http://118.98.234.50/lhun/daya_serap.aspx.
[15] C. Sahidu, Penilaian Hasil Belajar. Lombok Barat: Arga Puji Press, 2013.

[16] Trianto, Mendesain Pembelajaran Kontekstual (Contextual Teaching and Learning) di Kelas. Jakarta: Cerdas Pustaka, 2008.

[17] S. N. Hayati, H. Hikmawati, and W. Wahyudi, "Pengaruh model pembelajaran inkuiri dengan menggunakan media simulasi terhadap hasil belajar fisika siswa kelas X MIA SMAN 1 Lingsar Lombok Barat Tahun Pelajaran 2016/2017," J. Pendidik. Fis. dan Teknol., vol. 3, no. 1, pp. 48-54, 2017.

[18] R. Wahyuni, H. Hikmawati, and M. Taufik, "Pengaruh Model Pembelajaran Inkuiri Terbimbing dengan Metode Eksperimen terhadap Hasil Belajar Fisika Siswa Kelas XI IPA SMAN 2 Mataram Tahun Pelajaran 2016/2017," J. Pendidik. Fis. dan Teknol., vol. 2, no. 4, pp. 164-169, 2017.

[19] A. Abdi, "The Effect of Inquiry-Based Learning Method on Students' Academic Achievement in Science Course.," Univers. J. Educ. Res., vol. 2, no. 1, pp. 37-41, 2014. 